\title{
Analisis Komponen Desain Layout, Warna, dan Kontrol Pada Antarmuka Pengguna Aplikasi Mobile Berdasarkan Kemudahan Penggunaan (Studi Kasus: Aplikasi Olride)
}

\author{
Muhammad Nauval El Ghiffary, Tony Dwi Susanto, dan Anisah Herdiyanti \\ Departemen Sistem Informasi, Fakultas Teknologi Informasi dan Komunikasi, Institut Teknologi Sepuluh \\ Nopember (ITS) \\ e-mail: anisah@is.its.ac.id
}

\begin{abstract}
Abstrak-Meningkatnya penggunaan smartphone di dunia salah satunya disebabkan karena aplikasi mobile yang semakin beragam. Dengan banyaknya aplikasi yang beredar, maka pengembang aplikasi mobile semakin berlomba-lomba untuk membuat aplikasi yang menarik, salah satunya dari sisi tampilan. User Interface (UI) atau tampilan antarmuka pengguna menjadi daya tarik utama dalam sebuah aplikasi. Sebuah aplikasi dikatakan mudah untuk digunakan ketika pengguna dapat mengerti maksud dari tampilan antarmuka dan bagaimana mengoperasikan aplikasi tersebut dengan cepat dan tanpa perlu usaha yang banyak. Tujuan dari penelitian ini adalah untuk mengetahui komponen desain UI yang mudah digunakan menurut pengguna dan lebih user-friendly menggunakan analisis pada gelombang otak melalui NeuroS ky MindWave dan juga kuesioner yang mengadaptasi dari Technology Acceptance Model (TAM) untuk mengetahui persepsi kemudahan penggunaan aplikasi. Aplikasi yang digunakan sebagai studi kasus pada penelitian ini adalah Aplikasi Olride sebagai salah satu aplikasi yang termasuk dalam kategori Productivity pada Google Play Store. Hasil dari penelitian ini memberikan rekomendasi bahwa warna jingga lebih mudah digunakan untuk aplikasi mobile karena kontras yang tidak terlalu tinggi dengan kombinasi warna lainnya. Dan juga kontrol UI yang lebih mudah digunakan adalah kontrol dengan icon dan teks penjelas supaya pengguna dapat fokus kepada icon untuk navigasi dan teks sebagai penjelas dari fungsi icon tersebut. Untuk komponen desain layout tidak memberikan pengaruh yang signifikan terhadap kemudahan penggunaan yang dirasakan oleh pengguna aplikasi mobile.
\end{abstract}

Kata Kunci-Analisis Gelombang Otak, Aplikasi mobile, Desain User Interface, Ease of Use, Usability.

\section{PENDAHULUAN}

$\mathrm{P}$ ENINGKATAN pengguna smartphone di dunia salah satunya disebabkan karena aplikasi mobile yang semakin beragam. Dengan banyaknya aplikasi yang beredar, maka pengembang aplikasi mobile semakin berlomba-lomba untuk membuat aplikasi yang menarik, salah satunya dari sisi tampilan.. User Interface atau tampilan antarmuka pengguna merupakan bagian yang penting dalam sebuah sistem atau aplikasi. UI adalah bagian dari sistem yang digunakan untuk berinteraksi langsung dari pengguna. Oleh karena itu, desain dari UI menjadi salah satu daya tarik yang berpengaruh, terutama bagi sebuah aplikasi mobile [1].

Aplikasi Olride merupakan salah satu dari banyaknya aplikasi yang beredar di pasar aplikasi smartphone. Olride menonjolkan fungsinya yang terbilang cukup unik, yaitu layanan untuk booking bengkel secara online. Aplikasi Olride sebagai salah satu aplikasi yang termasuk dalam kategori Productivity pada Google Play Store. Olride menggunakan metode Design Sprint, metode yang disusun supaya prototipe dari aplikasi diuji dan disetujui oleh anggota timnya sendiri untuk mengutamakan kecepatan pengembangan aplikasi Sehingga Olride masih dapat menerima berbagai masukan terkait penyusunan desain aplikasinya.

Hal tersebut yang melatarbelakangi munculnya penelitian ini. Tujuan dari penelitian ini adalah untuk mengetahui komponen desain UI yang mudah digunakan menurut pengguna dan lebih user-friendly. Beberapa komponen desain antarmuka yang diujikan dalam penelitian ini adalah layout, warna, dan kontrol Dengan mengetahui desain tampilan antarmuka yang mudah digunakan maka pengembang aplikasi akan dapat membuat aplikasi yang menarik pengguna untuk menggunakan aplikasinya. Dari sisi pengguna diharapkan semua aplikasi untuk ke depannya menggunakan desain tampilan antarmuka yang user-friendly sehingga pengguna tidak perlu merasa terganggu ketika menggunakan sebuah aplikasi.

\section{TINJAUAN PUSTAKA}

\section{A. Desain Antarmuka Pengguna}

Antarmuka pengguna atau user interface (UI) adalah suatu istilah yang digunakan untuk menggambarkan tampilan dari mesin atau komputer yang berinteraksi langsung dengan pengguna. Desain dan penyusunan tampilan antarmuka perlu diperhatikan untuk menghasilkan tampilan yang bagus. Schlatter (2013) memberikan sebuah panduan untuk menyusun sebuah desain aplikasi yang mudah digunakan dengan 
membaginya ke dalam beberapa komponen yang berpengaruh sebagai berikut [2]:

- Consistency : konsistensi dari tampilan antarmuka pengguna

- Hierarchy : penyusunan hirarki kepentingan dari obyek-obyek yang terdapat di dalam aplikasi

- Personality : kesan pertama yang terlihat pada aplikasi yang menunjukkan ciri khas dari aplikasi tersebut.

- Layout : tata letak dari elemen-elemen di dalam sebuah aplikasi.

- Type : tipografi yang digunakan di dalam sebuah aplikasi

- Color : penggunaan warna yang tepat digunakan pada sebuah aplikasi.

- Imagery : penggunaan gambar, icon, dan sejenisnya untuk menyampaikan sebuah informasi di dalam aplikasi.

- Control and Affordances : elemen dari antarmuka pengguna yang dapat digunakan orang untuk berinteraksi dengan sistem melalui sebuah layar.

Petunjuk penyusunan desain antarmuka pengguna dalam sebuah aplikasi mobile berbeda-beda tergantung dari sistem operasi yang menjalankannya. Dalam studi kasus ini, aplikasi yang digunakan berbasis Android, maka acuan dari penyusunan penelitian yang akan dilakukan adalah prinsip desain Android atau lebih dikenal dengan sebutan Material Design Guidelines.

\section{B. Material Design Guidelines}

Material Design merupakan sebuah kerangka kerja untuk desain visual produk Google. Seluruh produk dari Google, termasuk Android, mengacu pada panduan desain yang disebut Material Design Guidelines. Berikut adalah beberapa komponen dari Material Design Guideline yang akan dianalisis dalam penelitian ini.

Layout : Di dalam Material Design, elemen layout dikelompokkan menjadi 5 kategori [3]. Berikut adalah kategori layout di dalam Android beserta elemenelemennya:

$\circ$ Units \& Measurement : melingkupi pixel density, density-independent pixels (dp), scaleable pixel (sp), dan image scaling.

○ Metrics \& Keylines : melingkupi baseline grid, spacing, keylines, increment sizing, dan touch target size.

- Structure : melingkupi UI region, Toolbars, App bar, System bars, Side nav, dan whiteframes

- Responsive UI : melingkupi breakpoints, grid, surface behaviors, dan patterns

○ Split Screen : melingkupi usage, behavior, dan layout

Dalam penelitian ini akan dibuat layout alternatif dengan mengubah struktur toolbar dan area konten dari tampilan aplikasi Olride yang nantinya akan digunakan untuk mencari layout mana yang paling mudah untuk digunakan.
Warna : Warna yang digunakan untuk menarik perhatian dari pengguna harus diletakkan secara strategis dan penggunaan warna yang konsisten juga akan membantu pengguna untuk memahami aplikasi tersebut [2]. Dari Material Design Guidelines, prinsip penggunaan warna untuk Android adalah menggunakan warna yang berani sebagai daya tarik dan dikelilingi oleh warna yang lebih halus sebagai latar utama, serta menonjolkan efek shadow dan warna terang untuk menarik perhatian. Material Design telah menyediakan banyak sekali panduan untuk digunakan ke dalam sebuah aplikasi. Penelitian ini akan menguji beberapa alternatif warna untuk digunakan ke dalam sebuah aplikasi.

Kontrol : Kontrol merupakan segala sesuatu yang memungkinkan pengguna berinteraksi dengan data melalui tampilan antarmuka [2]. Sebuah kontrol, baik itu berupa tombol atau ikon, harus menunjukkan bahwa pengguna dapat berinteraksi dengan kontrol tersebut.

Istilah kontrol dalam Material Design disebut sebagai komponen dan mencakup banyak sekali komponenkomponen kontrol yang ada di dalam sebuah aplikasi seperti tombol, slider, tab, text field, dll. Penelitian ini akan menguji tab sebagai komponen utama yang terdapat pada aplikasi Olride. Bentuk tab dari aplikasi Android yang banyak digunakan akan diambil sebagai alternatif untuk pengujian komponen ini.

\section{Kemudahan Penggunaan}

Kemudahan penggunaan adalah suatu aspek dalam teknologi yang bergabung bersama aspek-aspek lain yang menyusun teknologi tersebut. Dari ISO [4], dan penelitian oleh Nielsen [5], dapat dikatakan bahwa usability adalah kemudahan penggunaan dari sebuah teknologi dari sudut pandang pengguna teknologi tersebut.

Kemudahan penggunaan terdapat pada teori penerimaan teknologi yang sudah ada dan banyak teruji, salah satunya pada teori Technology Acceptance Model (TAM) dengan nama Perceived Ease of Use. Gambar 2.1 menunjukkan variabel kemudahan penggunaan pada TAM [6].

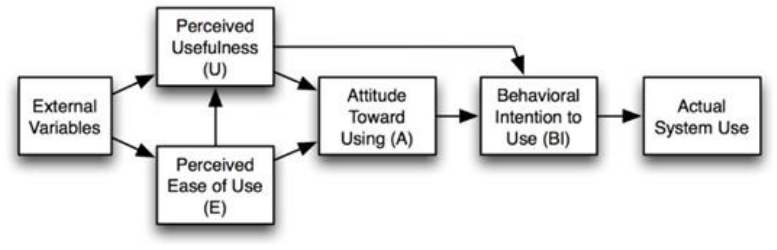

Gambar 1. Technology Acceptance Model.

Dari beberapa penelitian yang dilakukan, variabel kemudahan penggunaan telah menunjukkan hubungan yang sangat kuat terhadap niat penggunaan dan penggunaan sistem secara nyata [7][8], dan [9]. Sehingga penelitian ini akan menggunakan kuesioner berdasarkan dari variabel Perceived Ease of Use teori TAM untuk memperoleh persepsi kemudahan pengguna. 


\section{Gelombang Otak}

Penelitian ini akan menggunakan pembacaan gelombang otak untuk mengetahui tingkat konsentrasi yang dialami oleh seseorang ketika menggunakan aplikasi mobile. Kemudahan penggunaan ditandai dengan gelombang otak yang menunjukkan relaksasi dari pengguna.

Pembacaan gelombang otak akan dibantu dengan alat NeuroSky MindWave yang khusus untuk membaca gelombang otak. Alat ini akan menangkap gelombang otak dari pengguna, dan terbaca dalam software Meditation Journal pada komputer dalam bentuk nilai Meditation dan Attention. Semakin tinggi nilai Meditation yang keluar menandakan semakin rileks individu tersebut dan sebaliknya.

\section{E. Aplikasi Olride}

Aplikasi Olride adalah sebuah produk dari perusahaan Startup yang bernama PT. Olride Kreasi Digital. Aplikasi Olride menyediakan layanan untuk melakukan pemesanan antrian servis motor di bengkel. Aplikasi ini tersedia untuk smartphone dengan sistem operasi Android. Gambar 2 adalah beberapa contoh tampilan dari aplikasi Olride.
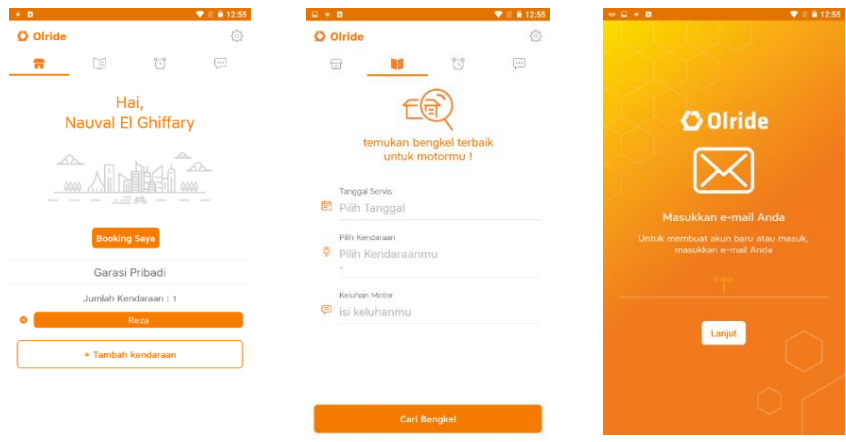

Gambar 2. Tampilan Aplikasi Olride.

\section{METODE PENELITIAN}

\section{A. Model Penelitian}

Seperti yang telah dijelaskan sebelumnya, penelitian ini bertujuan untuk mengetahui komponen desain antarmuka yang mudah digunakan oleh pengguna. Gambar 3 menjelaskan model yang menggambarkan kerangka dari permasalahan yang diangkat pada penelitan ini.

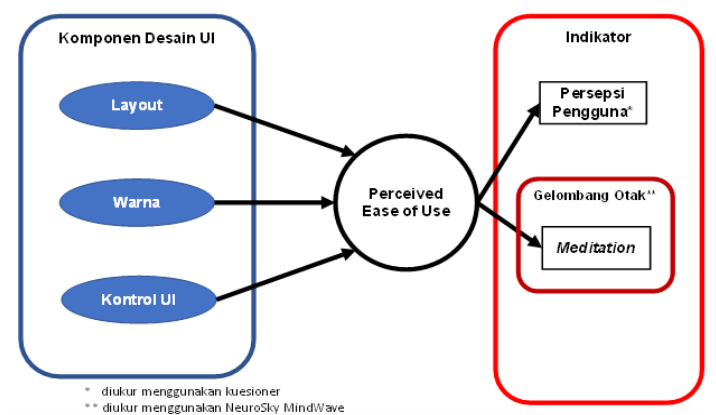

Gambar 3. Model Penelitian.
Percobaan pada masing-masing komponen desain dilakukan dengan menguji beberapa desain alternatif dari aplikasi aslinya. Alternatif dari setiap komponen desain diambil dari aplikasi lain yang sudah banyak digunakan oleh pengguna smartphone karena pengguna lebih terbiasa dengan tampilan aplikasi yang sering dilihat oleh mereka. Indikator yang digunakan sebagai pengukuran persepsi kemudahan penggunaan ada dua, yaitu persepsi pengguna yang akan diukur menggunakan kuesioner dan nilai Meditation dari gelombang otak pengguna yang akan diukur menggunakan alat NeuroSky MindWave. Kedua indikator ini akan dianalisis secara terpisah dan digunakan sebagai pendukung antara satu dengan yang lainnya. Harapan peneliti untuk dapat menggunakan kedua indikator ini sebagai bahan analisis adalah supaya dapat memberikan hasil yang sangat merepresentasikan persepsi kemudahan penggunaan dari pengguna.

\section{B. Pengumpulan Data}

Pengumpulan data akan dilaksanakan menggunakan teknik Random Convenient Sampling, yaitu dengan cara mengambil responden yang bersedia untuk mengikuti penelitian secara acak. Responden utama dari penelitian ini adalah target market dari aplikasi Olride yaitu orang dengan usia 17 tahun ke atas dan memiliki kendaraan sendiri serta pernah melakukan servis kendaraan ke bengkel. Jumlah responden yang akan digunakan untuk penelitian ini paling sedikit berjumlah 100 orang .

Responden penelitian akan diminta untuk mencoba desain antarmuka yang dirancang khusus untuk penelitian ini. Perekaman gelombang otak dilakukan saat responden melakukan simulasi penggunaan aplikasi dengan tampilan antarmuka yang didesain untuk penelitian ini dan sebelum mengisi kuesioner untuk mendapatkan gelombang otak yang sama seperti ketika pengguna sedang menggunakan aplikasi Olride. Kemudian responden diminta untuk mengisi kuesioner setelah responden menggunakan aplikasi dengan tampilan antarmuka yang sudah didesain untuk penelitian ini sehingga responden dapat langsung memberikan penilaian terhadap tampilan antarmuka yang telah dicoba.

\section{Penyusunan Perangkat Penelitian}

Penelitian ini membutuhkan beberapa perangkat untuk mendapatkan sebuah hasil. Berikut adalah beberapa perangkat yang digunakan dalam penelitian ini dan penyusunannya.

\section{1) Prototipe Aplikasi}

Pembuatan prototipe aplikasi Olride mengacu pada rencana skenario dan alternatif dari masing-masing komponen tampilan antarmuka.

Layout

Alternatif layout dari aplikasi Olride yang dibuat dibedakan menjadi dua alternatif, yaitu daerah Toolbar utama yang berada di bagian atas layar (layout asli aplikasi Olride) dan di bawah layar. Layout alternatif ini dibuat berdasarkan layout dari aplikasi yang sudah banyak digunakan oleh orang seperti Instagram(1 miliar download), dan OLX (1 juta download). 
Warna

Alternatif warna dari aplikasi Olride yang dibuat dibedakan menjadi dua alternatif, yaitu warna jingga (warna asli aplikasi Olride) dan warna biru. Peneliti memutuskan untuk menggunakan kedua warna tersebut dari percobaan yang dilakukan oleh website yang berfokus pada analisis tentang perangkat mobile menunjukkan bahwa aplikasi-aplikasi yang terkenal dan banyak digunakan menggunakan warna utama merah, biru, dan jingga. Dan untuk kategori produktivitas, yang sama dengan kategori studi kasus aplikasi Olride, warna yang banyak digunakan adalah biru, hijau, kuning, dan jingga [10].

\section{Kontrol UI}

Alternatif kontrol UI dari aplikasi Olride yang akan diujikan pada penelitian ini adalah Tab yang terdapat pada toolbar utama aplikasi. Alternatif kontrol UI yang dibuat dibedakan menjadi tiga alternatif, yaitu tab dengan icon (kontrol UI asli aplikasi Olride), tab dengan teks, dan tab dengan icon dan teks.

\section{2) Perancangan Kuesioner Penelitian}

Kuesioner yang digunakan pada penelitian ini bertujuan untuk mengetahui persepsi kemudahan menurut pengguna dalam menggunakan tampilan dari aplikasi. Pembuatan item dalam kuesioner ini menggunakan item-item pertanyaan dari penelitian lain dengan tema yang sama [11], dengan kalimat yang disesuaikan untuk penelitian ini pada setiap poinnya. Tabel 1 merupakan kuesioner yang digunakan dalam penelitian ini beserta sumbernya.

\section{3) Perancangan Skenario Pengumpulan Data}

Skenario pengumpulan data untuk penelitian adalah proses atau tahapan yang dilakukan peneliti ketika melakukan pengambilan data penelitian.

Responden akan diberi penjelasan tentang tujuan penelitian ini dan maksud dari pengambilan data. Kemudian responden akan dipasangkan alat NeuroSky dan diberikan smartphone yang akan digunakan responden untuk menyelesaikan tugas yang diberikan. Peneliti juga akan menjelaskan cara penggunaan smartphone sebelum memberikan perintah pengerjaan tugas. Selanjutnya responden melakukan tugas yang diberikan menggunakan smartphone yang disediakan. Setelah menyelesaikan tugas, responden mengisi kuesioner yang tersedia sembari peneliti mengatur smartphone untuk komponen selanjutnya. Langkah-langkah tersebut dilaksanakan hingga seluruh desain yang akan diujikan telah digunakan oleh responden. Setelah semua desain selesai diujikan, peneliti menanyakan kepada responden tentang pilihan desain yang lebih mudah dari masing-masing komponen yang diujikan.

\section{Analisis Data}

Beberapa teknik analisis data yang akan digunakan pada penelitian ini adalah analis is deskriptif dan analisis komparatif.

Analisis deskriptif digunakan untuk menggambarkan data yang didapatkan dari pengumpulan data tanpa membuat suatu kesimpulan umum. Analisis deskriptif akan digunakan untuk mendeskripsikan data kuesioner berdasarkan kecenderungan tanggapan responden terhadap pernyataan dari variabel persepsi kemudahan penggunaan. Hasil rekam gelombang otak akan dianalisis dengan cara mencari rata-rata dan standar deviasi dari nilai gelombang otak yang dihasilkan .

Analis is komparatif digunakan untuk mencari perbedaan dari data antar kategori yang didapatkan. Pada penelitian ini, analisis komparatif akan digunakan untuk melihat perbedaan rata-rata dalam hasil yang didapat dari masing-masing alternatif di dalam sebuah komponen desain UI. Analisis komparatif dilakukan dengan melakukan uji ANOVA atau T-test pada masing-masing alternatif di dalam satu komponen desain.

\section{HASIL DAN PEMBAHASAN}

\section{A. Analisis Deskriptif}

Analisis deskriptif data yang akan ditunjukkan meliputi nilai minimum dan maksimum, nilai rata-rata (mean), dan standar deviasi untuk setiap alternatif desain yang diujikan. Pembahasan analisis deskriptif pada Tabel 4.1 menjelaskan data dari masing-masing desain komponen yang diujikan dengan menunjukkan nilai rata-rata dari seluruh kuesioner. Untuk komponen layout terdapat dua alternatif yaitu tab utama yang terletak di atas (top) dan terletak di bawah (down). Untuk komponen warna terdapat dua alternatif yaitu warna jingga (orange) dan warna biru (blue). Dan untuk komponen kontrol terdapat tiga alternatif yaitu tab dengan icon (ctrll), tab dengan teks (ctrl2), dan tab dengan icon dan teks (ctrl3). Nilai meditasi dari rekam gelombang otak dijelaskan pada bagian bawah Tabel 1.

Tabel 1.

Hasil Analisis Deskriptif

\begin{tabular}{|c|c|c|c|c|}
\hline Item & Minimum & Maximum & Mean & $\begin{array}{c}\text { Std. } \\
\text { Deviation }\end{array}$ \\
\hline \multicolumn{5}{|c|}{ Data Kuesioner } \\
\hline top & 3 & 7 & $\underline{5,298}$ & $\underline{0,937}$ \\
\hline down & 3 & 7 & $\underline{5,282}$ & $\underline{0,941}$ \\
\hline orange & 3 & 7 & $\underline{5,286}$ & $\underline{0,922}$ \\
\hline blue & 2 & 7 & $\underline{5,220}$ & $\underline{1,025}$ \\
\hline ctrl1 & 2,8 & 7 & $\underline{5,330}$ & $\underline{0,926}$ \\
\hline $\operatorname{ctrl} 2$ & 3,8 & 7 & $\underline{5,842}$ & $\underline{0,798}$ \\
\hline $\operatorname{ctrl} 3$ & 4,4 & 7 & $\underline{6,080}$ & $\underline{0,745}$ \\
\hline \multicolumn{5}{|c|}{ Data Rekam Gelombang Otak } \\
\hline top_med & 33 & 69 & $\underline{51,81}$ & $\underline{7,240}$ \\
\hline down_med & 32 & 67 & $\underline{50,37}$ & $\underline{7,132}$ \\
\hline orange_med & 35 & 63 & $\underline{51,39}$ & $\underline{6,108}$ \\
\hline blue_med & 28 & 63 & $\underline{49,16}$ & $\underline{7,232}$ \\
\hline ctrl1_med & 34 & 61 & $\underline{48,53}$ & $\underline{6,203}$ \\
\hline ctrl2_med & 34 & 63 & $\underline{48,66}$ & $\underline{6,051}$ \\
\hline ctrl3_med & 29 & 63 & $\underline{47,99}$ & $\underline{5,493}$ \\
\hline
\end{tabular}

Nilai rata-rata atau Mean dari hasil analisis tersebut nantinya akan digunakan untuk mengetahui desain alternatif mana yang lebih mudah digunakan untuk aplikasi.

\section{B. Analisis Komparatif}

Dalam analisis komparatif dilakukan uji t dan ANOVA untuk 
mengetahui apakah desain dari masing-masing komponen tampilan antarmuka yang diujikan memiliki perbedaan yang signifikan. Hasil dari uji t dan ANOVA dapat dilihat pada Tabel 2 berikut.

Tabel 2.

Hasil uji t dan ANOVA

\begin{tabular}{lcc}
\hline \hline Data & Kuesioner & $\begin{array}{c}\text { Nilai Meditasi } \\
\text { Rekam Gelombang } \\
\text { Komponen }\end{array}$ \\
\hline Layout & Tidak Signifikan & Tidak Signifikan \\
Warna & Tidak Signifikan & Signifikan \\
Kontrol & Signifikan & Tidak Signifikan \\
\hline \hline
\end{tabular}

Desain alternatif yang terdapat pada komponen layout tidak menunjukkan adanya perbedaan yang signifikan baik melalui data kuesioner maupun data rekam gelombang otak. Hal ini diutarakan oleh 12 responden yang menyebut bahwa dari kedua layout tidak ada yang berbeda. Dengan ini, desain komponen layout dengan posisi layout menu utama di atas maupun di bawah tidak memberikan pengaruh yang signifikan terhadap kemudahan penggunaan aplikasi.

Untuk komponen desain warna, hasil uji t menunjukkan bahwa data kuesioner tidak memiliki perbedaan yang signifikan tetapi data rekam gelombang otak menunjukkan adanya perbedaan yang signifikan antara kedua desain alternatifnya. Signifikansi yang berbeda antara hasil kuesioner dengan rekam gelombang otak dapat disebabkan karena sinyal/spektrum warna dapat langsung ditangkap oleh otak dan menyebabkan peningkatan pada aktivitas elektrisitas di otak yang tertangkap oleh EEG [12]. Sehingga data yang akan digunakan untuk memilih desain alternatif yang terbaik dalam komponen warna adalah data rekam gelombang otak.

Untuk komponen desain kontrol, hasil uji ANOVA menunjukkan bahwa data rekam gelombang otak tidak memiliki perbedaan yang signifikan antara ketiga desain alternatifnya tetapi data kuesioner menunjukkan terdapat perbedaan yang signifikan. Hal ini terjadi karena pengguna mencoba memahami icon dengan menggunakan pengalaman pribadinya. Tingkat relaksasi atau aktivitas dari gelombang otak tidak terpengaruh ketika pengguna mencoba mengingat sesuatu dari pengalamannya (secara perilaku), bukan ketika mengingat suatu rumus atau informasi (secara kognitif) [13]. Maka data kuesioner dari komponen kontrol dapat digunakan untuk mencari desain antarmuka alternatif terbaik pada komponen ini.

\section{Penentuan Hasil Penelitian}

Untuk dapat menentukan desain terbaik dalam masingmasing komponen desain antarmuka maka perlu dilakukan perbandingan antar desain dalam satu kelompok komponen.

Dalam komponen desain warna terdapat dua alternatif desain yang akan dibandingkan menggunakan nilai meditasi gelombang otak dengan skala 1 sampai 100. Perbedaan nilai rata-rata pada hasil rekam gelombang otak komponen warna terbilang signifikan dengan selisih nilai rata-rata sampel 2,23 dengan desain warna jingga lebih unggul dibanding desain warna biru. Walaupun perbedaan nilai rata-rata dari kedua data sampel hanya 2,23 tetapi jika dilihat dari standar deviasi data yang cukup kecil yaitu 6,1 untuk data warna jingga dan 7,2 untuk data warna biru menunjukkan bahwa distribusi data tidak terlalu menyimpang dari nilai rata-rata data sehingga selisih nilai rata-rata tersebut sudah cukup untuk membuat perbedaan yang signifikan diantara kedua desain warna tersebut. Dari analisis yang sudah dilakukan dapat diambil kesimpulan bahwa desain warna yang mudah digunakan pengguna pada aplikasi Olride adalah warna jingga atau orange dengan rata-rata nilai meditasi 51,39, lebih baik dari warna biru dengan rata-rata nilai meditasi 49,16.

Dalam komponen desain kontrol terdapat tiga alternatif desain yang akan dibandingkan menggunakan nilai kuesioner tentang persepsi kemudahan penggunaan dengan skala likert 1 sampai 7. Tiga desain alternatif pada komponen kontrol yaitu kontrol dengan tab icon(ctrl1), kontrol dengan tab teks(ctrl2), dan kontrol dengan tab icon dan teks (ctrl3). Rata-rata nilai kuesioner dari alternatif desain ctrl1, ctrl2, dan ctrl3 secara berurutan adalah 5,$33 ; 5,84 ;$ dan 6,08 . Untuk nilai rata-rata dari sebuah skala likert 7 poin, selisih nilai dari ketiga desain alternatif tersebut dapat dikatakan cukup jauh berbeda. Salah satu metode untuk membandingkan lebih dari dua kelompok data adalah dengan tes S-N-K (Student-Newman-Keuls). Tujuan dari tes S-N-K ini adalah untuk memberikan informasi tentang homogenitas data dari setiap variabel dan kategori atau faktor yang dibandingkan. Maka yang perlu dilihat dari hasil tes S-N-K adalah nilai rata-rata yang berada pada pojok kanan bawah karena yang dicari adalah nilai dengan rata-rata yang paling tinggi dan berbeda dengan yang lain. Maka yang perlu dilihat dari hasil tes S-N-K adalah. Sehingga desain kontrol yang mudah digunakan pengguna pada aplikasi Olride adalah kontrol dengan tab icon dan teks yang memiliki nilai rata-rata persepsi kemudahan penggunaan 6,08 seperti ditunjukkan pada Gambar 4.

ctr11_2_3

Student-Newman-Keuls.
\begin{tabular}{|l|c|c|c|c|}
\hline \multirow{2}{*}{ control } & & \multicolumn{3}{|c|}{ Subset for alpha $=0.05$} \\
\cline { 3 - 5 } & 100 & 1 & 2 & \multicolumn{1}{c|}{3} \\
\hline 1 & 100 & & 5,8300 & \\
2 & 100 & & & 6,0800 \\
3 & & 1,000 & 1,000 & 1,000 \\
\hline
\end{tabular}

Gambar 4. Hasil Tes S-N-K Komponen Kontrol

\section{KESIMPULAN/RINGKASAN}

\section{A. Kesimpulan}

Penelitian ini berfokus untuk mengetahui desain antarmuka 
untuk aplikasi mobile yang mudah untuk digunakan oleh pengguna aplikasi. Di dalam penelitian ini dilakukan analisis terhadap tiga komponen desain antarmuka yaitu layout, warna, dan kontrol. Dari hasil penelitian ini diperoleh beberapa temuan sebagai berikut:

1. Komponen desain layout dengan menu utama berbentuk baris seperti pada studi kasus aplikasi Olride tidak memiliki pengaruh yang signifikan terhadap kemudahan penggunaan aplikasi, baik dengan layout menu di bagian atas atau di bagian bawah yang dibuktikan dengan hasil uji t antara kedua desain yang diujikan untuk komponen layout tidak menunjukkan adanya perbedaan yang signifikan sehingga dianggap tata letak menu utama di bagian atas atau bawah tidak berpengaruh terhadap kemudahan penggunaan.

2. Warna jingga atau orange lebih mudah digunakan untuk aplikasi dengan kategori produktivitas seperti aplikasi Olride jika dibandingkan dengan warna biru.

Hal ini dibuktikan dengan nilai rata-rata gelombang otak yang menunjukkan bahwa pengguna yang sama merasa lebih rileks saat menggunakan aplikasi dengan warna jingga dibandingkan saat menggunakan aplikasi dengan warna biru.

3. Komponen desain kontrol yang mudah digunakan oleh pengguna adalah kontrol dengan icon dan teks penjelas. Dari hasil penelitian ditunjukkan dengan nilai rata-rata kuesioner kemudahan penggunaan bahwa pengguna merasa lebih mudah menggunakan tampilan dengan kontrol icon dan teks penjelas dibandingkan dengan kontrol yang hanya berupa icon maupun kontrol yang hanya teks saja.

\section{B. Rekomendasi}

Dari pembahasan hasil analisis dan kesimpulan dari penelitian ini telah didapatkan beberapa temuan yang bisa menjadi rekomendasi atau masukan untuk penggunaan desain tampilan antarmuka pada aplikasi mobile. Rekomendasi yang diberikan dari hasil penelitian ini adalah :

- Komponen layout dengan peletakan baris menu utama yang terletak di bagian atas konten maupun di bagian bawah konten tidak memengaruhi kemudahan pengguna untuk mengoperasikan sebuah aplikasi..

- Warna jingga atau orange lebih mudah digunakan untuk aplikasi dengan kategori produktivitas seperti aplikasi Olride jika dibandingkan dengan warna biru. Dari hasil rekam gelombang otak menunjukkan bahwa warna jingga membuat responden merasa lebih tenang atau rileks jika dibandingkan dengan warna biru.

- Komponen desain kontrol yang mudah digunakan oleh pengguna adalah kontrol dengan icon dan teks penjelas. Salah satu responden juga memberikan pendapat bahwa kontrol dengan icon dan teks memudahkan navigasi dan lebih menarik fokus kepada menu utama.

\section{Saran}

Penelitian ini masih memiliki banyak kesempatan untuk dilakukan penelitian lebih lanjut. Berikut ini adalah saran yang dapat diberikan oleh peneliti untuk penelitian selanjutnya agar bisa memberikan dampak lebih besar pada bidang keilmuan ini:

1. Pendekatan yang dilakukan untuk meneliti tampilan antarmuka berdasarkan kemudahan penggunaan masih sangat banyak dan beragam sehingga masih banyak kesempatan untuk memperkaya pengetahuan pada topik ini.

2. Komponen desain antarmuka yang diujikan pada penelitian ini masih terbatas. Banyak komponen desain lainnya yang dapat diujicobakan dan banyak referensi desain lainnya yang masih belum dieks plorasi.

\section{DAFTAR PUSTAKA}

[1] A. Tarute, S. Nikou, and R. Gatautis, "Mobile application driven consumer engagement," Telemat. Informatics, vol. 34, no. 4, pp. 145-156, 2017.

[2] T. Schlatter and D. Levinson, Visual Usability: Principles and Practices for Designing Digital Applications. Elsevier, 2013.

[3] Google, "Principles - Layout - Material Design guidelines," material.io, 2017. [Online]. Available: https://material.io/guidelines/layout/principles.html.

[4] International Standards Organization, "Ergonomic requirements for office work with visual display terminals (VDTs) - Part 11: Guidance on usability ISO 9241-11," 1998.

[5] J. Nielsen, "Nielsen Norman Group," 2012. [Online]. Available: https://www.nngroup.com/articles/usability-101introduction-to-usability/.

[6] F. D. Davis, R. Bagozzi, and P. Warshaw, "User acceptance of computer technology: a comparison of two theoretical models," Manage. Sci., vol. 35, pp. 181-192, 1989.

[7] L. Li, "A critical review of technology acceptance literature," 2010.

[8] R. Hanafi, "Analisis faktor-faktor yang mempengaruhi tingkat penerimaan aplikasi blood bank information system," Surabaya, 2015.

[9] J.-H. Huang, Y. Lin, and S. Chuang, "Elucidating user behavior of mobile learning," Electron. Libr., vol. 25, no. 5, pp. 585$598,2007$.

[10] J. Brownlee, "Cult of Mac," cultofmac.com, 2014. [Online]. Available: http://www.cultofmac.com/270606/popular-colorsios-7-app-store-infographic/.

[11] F. Davis, "Perceived usefulness, perceived ease of use, and user acceptance of information technology," Manag. Inf. Syst., pp. 319-340, 1989.

[12] R. KÜLLER, "Physiological and Psychological Effects of Illumination and Colour in the Interior Environment," J. Light Vis. Environ., vol. 10, no. 2, pp. 33-37, 1986. 